\title{
Determinan Persepsi Pengguna, Kepuasaan Pengguna dan Kesuksesan Implementasi E-Budgeting di Pemerintah Kota Surakarta
}

\author{
(Studi Kasus Pada Organisasi Pemerintah Daerah Kota Surakarta)
}

\author{
Rihan Mustafa Zahri \\ Universitas PGRI Madiun \\ rihanmustafa@unipma.ac.id
}

\author{
Dinda Amelia Kusumastuti \\ Universitas PGRI Madiun \\ dindakusumastuti@gmail.com
}

\begin{abstract}
ABSTRAK
Penelitian ini bertujuan untuk menguji tingkat kesuksesan model sistem $e$-budgeting pada pemerintah kota Surakarta dengan menggunakan D\&M IS Succes Model. Penelitian ini menggunakan metode observasi dan survei dengan mengumpulan data primer berupa kuesioner dibantu dengan menggunakan sotware Analysis of Moment Structure (AMOS) IBM 23 dan wawancara. Populasi Organisasi Perangkat Daerah (OPD) di pemerintah kota Surakarta terkait penyusunan anggaran menggunakan e-budgeting. Hasil penelitian ini membuktikan bahwa kualitas sistem berpengaruh positif terhadap persepsi penggunaan e-budgeting. Kualitas sistem informasi e-budgeting berpengaruh tidak signifikan terhadap kepuasan pengguna e-budgeting. Kualitas informasi berpengaruh positif dan signifikan terhadap penggunaan e-budgeting. Kualitas informasi tidak berpengaruh terhadap kepuasan pengguna. Kualitas layanan berpengaruh positif dan signifikan terhadap penggunaan $e$-budgeting. Kualitas pelayanan tidak berpengaruh signifikan terhadap kepuasan pengguna. Persepsi penggunaan berpengaruh positif dan signifikan terhadap kepuasan pengguna. Persepsi penggunaan $e$-budgeting berpengaruh positif dan signifikan terhadap kinerja $e$-budgeting. Kepuasan pengguna berpengaruh positif terhadap kesuksesan atau kinerja $e$ budgeting.
\end{abstract}

Keyword: Kepuasan Pengguna, E-Budgeting, Pemerintahan

\section{PENDAHULUAN}

Perkembangan moderenisasi dalam pengelolaan sebuah organisasi proses bisnis banyak dipengaruhi oleh teknologi informasi dan sistem informasi untuk meningkatkan kualitas layanan (Purwohandoko, Sanaji dan Mustofa, 2015). Kualitas layanan yang baik dan sukses dinilai dari seberapa efisien dan efektifnya sistem pengelolaan dalam mengambil keputusan di sebuah organisasi (Wahyuni, 2011). Hal tersebut membuktikan bahwa pentingnya menggunakan teknologi informasi di berbagai aspek kehidupan seperti dalam kegiatan bisnis, pendidikan dan pemerintahan (Al-Fraihat, Joy dan Sinclair, 2017).

Pada instansi pemerintah di semua tingkatan, berusaha melakukan revolusi 
digital untuk meningkatkan kualitas layanan yang diberikan dengan mengubah struktur organisasinya berbasis web dan layanan online yang aktual (West, 2002). Dengan adanya sistem informasi di dalam instansi pemerintah, harapannya bisa menyederhanakan sistem kerja dan mencapai tata kelola yang baik (Purwohandoko, Sanaji dan Mustofa, 2015). Dikatakan Tata kelola yang baik atau good governance apabila sistem tersebut memberikan informasi yang transparan, akuntabel, efektif, efisien, produktif dalam melayani dan menerapkan standar akuntansi pemerintahan (SAP) berbasis akrual sesuai Peraturan Pemerintah Nomor 71 Tahun 2010 (Nasution, Erlina dan Sari, 2016).

Salah satu bentuk sistem informasi modern saat ini yang membantu terciptanya tata kelola yang baik didalam pemerintahan yaitu electronic budgeting (Soegoto dan Indra, 2018). E- budgeting mempunyai peran penting di instansi pemerintah untuk mewujudkan perencanaan dan penganggaran yang terbuka dan bertanggungjawab kepada masyarakat (Fajri, Djumali dan Hartono, 2019). Maka dari itu, Badan Pengawasan Keuangan dan Pembangunan (BPKP) merancang program aplikasi e-budgeting untuk dipakai kepada pemerintah daerah (Nasution dan Ramadhan, 2019).

Dalam pelaksanaannya pemerintah sudah mengupayakan atau mempunyai kemauan untuk mensukseskan implementasi e-budgeting di semua tingkatan pemerintah (Rokhman, 2011). Salah satu pemerintah daerah yang mengimplementasi e-budgeting adalah pemerintah kota Surakarta, dimana pemerintah Surakarta baru menjalankan sistem selama dua tahun tetapi telah memperoleh peringkat ke-5, berdasarkan hasil evaluasi dan monitoring terhadap 36 pemerintah daerah di Jateng yang dilakukan komisi pemberantasan korupsi (KPK) pada tahun2017 (Suara Merdeka, 2019). Pada tahun 2018 pemerintah kota Surakarta memperoleh pencapaian sebagai badan publik informatif peringkat ke-3 tingkat provinsi Jawa Tengah setelah kota Batang dalam penerapan sistem e-budgeting dan sistem pemerintahan yang lain (Laporan tahunan PPID kota Surakarta, 2018). Hal ini disimpulkan bahwa pemerintah kota Surakarta belum secara maksimal dalam mengembangkan sistem informasi didalam pemerintahannya, dikarenakan masih belum bisa mendapatkan peringkat terbaik di Provinsi Jawa Tengah.

Opini tersebut menjelaskan bahwa pemerintah kota Surakarta masih ada kekurangan dan membutuhkan evaluasi dalam meningkatkan lagi penerapan sistem $e$ budgeting di dalam pemerintah kota Surakarta. Berdasarkan latar belakang, peneliti ingin menguji tingkat kesuksesan model sistem $e$-budgeting di pemerintah kota Surakarta dengan menggunakan D\&M IS Succes Model yang dikembangkan oleh Delone dan McLean (Delone dan McLean, 2003). Model tersebut sangat efektif digunakan untuk sistem yang berbasis world wide web atau online dan model ini dapat digunakan untuk menentukan hubungan pengguna sistem dengan kinerja yang dihasilkan atau manfaat yang didapatkannya (Stefanovic et al., 2016 ; Balaban, Mu dan Divjak, 2013). Beberapa penelitian terkait dengan sistem informasi pada sektor pemerintahan dengan menggunakan $D \& M I S$ Success Model yaitu Wu dan Wang (2006), Wang dan Liao (2008), Mulyono (2009), 
Wahyuni (2011), Zaied (2012), Noviyanti (2016), Stefanovic et al. (2016), Putra dan Alfian (2016).

\section{TINJAUAN PUSTAKA}

\subsection{Sistem Informasi}

Perancangan sistim informasi dikatakan efektif dan efisien apabila sistem informasi sukses dalam menjalankan fungsinya (Wahyuni, 2011). Romney dan Paul (2012) menyatakan bahwa sistem informasi akuntansi (SIA) adalah suatu sistem yang mengumpulkan, mencatat, menyimpan dan mengolah data untuk menghasilkan informasi bagi pengambil keputusan. Sistem ini meliputi orang, prosedur dan instruksi, data, perangkat lunak, infrastuktur teknologi informasi, serta pengendalian internal dan ukuran keamanan.

Sistem informasi yang mendukung fungsi akuntansi selalu memainkan peran utama dalam organisasi baik sektor publik maupun bisnis (Baridwan, 2005). Sedangkan Loudon (2006); Romney et al. (2012) menyatakan bahwa sistem informasi akuntansi didesain untuk mendukung pengambilan keputusan, mengendalikan organisasi dan menambah nilai organisasi. Hal tersebut sejalan dengan indikator manfaat bersih organisasi dalam model kesuksesan sistem informasi dikemukakan oleh DeLone dan McLean (2003).

\subsection{D\&M IS Succes Model}

Model kesuksesan sistem informasi yang diperkenalkan oleh DeLone dan McLean (1992) didasari dengan riset komunikasi dari Shannon dan Weaver (1949) dan Influence Theory of Mason (1978) dengan mereview 180 artikel dalam studi penelitian empiris management information systems (MIS). DeLone dan McLean (1992) melakukan berbagai kajian teori dan hasil penelitian yang dipublikasikan tentang kesuksesan sistem informasi dari tahun 1981 sampai dengan 1987 dan menciptakan taxanomy kesuksesan sistem informasi, kemudian mengembangkan sebuah model yang disebut dengan nama D\&M IS Success Model. Kesuksesan sistem informasi dikatagorikan menjadi enam dimensi yaitu Kualitas Informasi (Information Quality), Kualitas Sistem (System Quality), Penggunaan Sistem (Use), Kepuasan Pengguna (User Satisfaction), Dampak Individual (Indiviual Impact), dan Dampak organisasi (Organizational Impact).

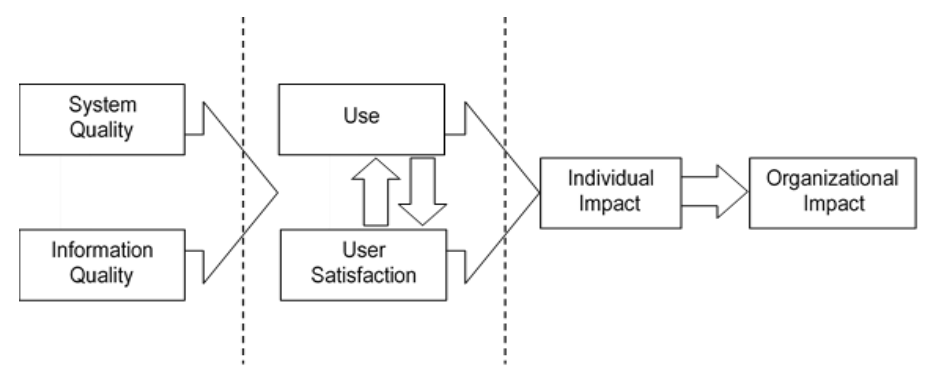

\section{Gambar 1. D\&M IS Succes Model (1992)}

D\&M IS Success Model yang dikembangkan DeLone dan McLean (1992) merupakan model yang paling banyak dikutip dalam penelitian akan kesuksesan sistem informasi (Thomas, 2008). Dengan mengkaji lebih dari 100 artikel yang dipublikasi pada jurnal seperti Information Systems Research (ISR), Journal of Management Information Systems (JMIS), MIS Quaterly, 10 tahun kemudian DeLone and McLean memperbaiki model kesuksesan sistem informasi yang dikenal dengan nama 
Updated D\&M IS Success Model. Model tersebut disajikan pada Gambar 2.

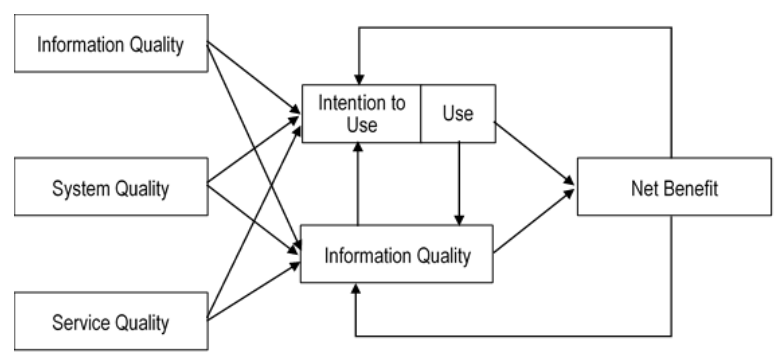

\section{Gambar 2. UpdateD\&M IS Succes Model (2003)}

Pada gambar terlihat perubahan dimensi yang dibangun yaitu dimensi kualitas layanan (service quality) dimasukkan sebagai tambahan dari dimensi-dimensi kualitas yang sudah ada, yaitu kualitas sistem (system quality) dan kualitas informasi (information quality). Dampak individual (individual impact) dan dampak organisasional (organizational impact) menjadi satu variabel yaitu manfaat-manfaat bersih (net benefits). Dimensi minat memakai (intention to use) sebagai alternatif tambahan dari dimensi penggunaan (use).

\subsection{E-Budgeting}

Sistem e-budgeting adalah sistem penyusunan anggaran yang didalamnya termasuk aplikasi program komputer berbasis web untuk memfasilitasi proses penyusunan APBD (Anggaran Pendapatan dan Belanja Daerah), revisi, dan PAK (Perubahan Anggaran Kegiatan) pemerintah Surakarta. Tujuan dibuatnya e-budgeting di dalam organisasi pemerintah diharapkan bisa mempermudah SKPD (Satuan Kerja Perangkat Daerah) dalam proses penyusunan anggaran dan meningkatkan kualitas APBD dari kesesuaian RPJMD (Rencana Pembangunan Jangka Menengah Daerah) dari sisi keakuratan nilai, rekening dan akuntabilitas alokasi belanja (Khoirunnisak, Arishanti dan Vebrianti, 2017).

Hal tersebut dilakukan untuk memperoleh performance anggaran yang baik, terarah, efisien dan efektif sehingga bisa terciptanya proses yang transparan dan akuntabel (Fajri et al., 2019). Dalam penyusunan anggaran dibutuhkan komponen-komponen penyusunan yang mana komponen-komponen penyusun tersebut merupakan hasil dari survei di lapangan. Komponen penyusun terdiri dari tiga jenis pengelompokan, yaitu standar harga satuan dasar (SHSD), harga satuan pokok kegiatan (HSPK), dan standart analisa belanja (SAB) (Gunawan, 2016). Dapat disimpulkan bahwa konsep e-budgeting merupakan pengembangan konsep budgeting yang merupakan salah satu financial tools di dalam mengelola suatu perusahaan atau pemerintah mulai dari perencanaan, pembuatan program, pelaksanaan program dan evaluasi.

\subsection{Pengembangan Hipotesis}

Kualitas sistem mencerminkan karakteristik kinerja dari sistem yang bersangkutan (DeLone dan McLean, 1992). Karakteristik yang diinginkan dari sebuah sistem informasi, misalnya: kemudahan penggunaan, sistem fleksibilitas, keandalan sistem, dan kemudahan mempelajarinya, termasuk adanya fitur yang intuitif, kecanggihan, fleksibilitas, dan waktu respon (Petter et al., 2008). Penelitian Wang dan Liao (2008), Wahyuni (2011), Zaied (2012), Noviyanti (2016), Stefanovic et al. (2016), menghasilkan pengaruh yang positif dan 
signfikan. Hasil tersebut menunjukkan bahwa pengaruh kualitas sistem sangat besar terhadap penggunaan sistem, sehingga dirumuskan hipotesis sebagai berikut:

$\mathrm{H}_{1}$ : Kualitas sistem berpengaruh positif terhadap penggunaan $e$-budgeting

Kualitas sistem informasi yang baik akan memudahkan pengguna dalam mengaplikasikannya, hal ini dapat menimbulkan kepuasan bagi penggunanya. Kualitas sistem berpengaruh positif dan signfikan terhadap kepuasan pengguna sesuai dengan penelitiannya Wang dan Liao (2008), Wahyuni (2011), Zaied (2012), Noviyanti (2016), Stefanovic et al. (2016). Hasil tersebut menunjukkan bahwa pengaruh kualitas sistem sangat besar terhadap kepuasan penggunanya, sehingga dirumuskan hipotesis sebagai berikut:

$\mathrm{H}_{2}$ : Kualitas sistem berpengaruh positif terhadap kepuasan penggunae-budgeting

Kualitas informasi adalah karakteristik yang diinginkan dari output sistem informasi yaitu, laporan manajemen dan halaman web yang relevan, dapat dimengerti, akurasi, keringkasan, kelengkapan, ketepatan waktu, dan kemanfaatan (Petter et al., 2008). Kualitas informasi merupakan ukuran dari kualitas output dari sistem informasi, termasuk di dalamnya bentuk laporan yang dihasilkan sistem (DeLone dan McLean, 1992). Kualitas informasi menitikberatkan pada hal yang relevan, batas waktu yang tepat, dan akurat yang dihasilkan dari sistem informasi. Hasil penelitian yang dilakukan oleh Wang dan Liao (2008), Mulyono (2009), Wahyuni (2011), Zaied (2012), Noviyanti (2016), Stefanovic et al. (2016), menunjukkan bahwa kualitas informasi berpengaruh positif dan signfikan terhadap penggunaaan. Hasil tersebut menunjukkan bahwa pengaruh kualitas informasi sangat besar terhadap penggunaan, sehingga dirumuskan hipotesis sebagai berikut:

$\mathrm{H}_{3}$ : Kualitas informasi berpengaruh positif terhadap penggunaan $e$-budgeting

Kualitas informasi yang baik, yaitu dapat dimengerti, akurasi, keringkasan, kelengkapan, ketepatan waktu, dan memberikan manfaat dapat menumbuhkan kepuasan bagi penggunanya. Hasil penelitian Petter et al. (2008) menunjukkan bahwa pengaruh kualitas informasi terhadap kepuasan pengguna terbukti signifikan oleh lima belas peneliti yang dikumpulkan. Hasil penelitian yang dilakukan oleh Wang dan Liao (2008), Mulyono (2009), Wahyuni (2011), Zaied (2012), Noviyanti (2016), Stefanovic et al. (2016) menunjukkan bahwa kualitas informasi berpengaruh signifikan terhadap kepuasan pengguna. Berdasarkan hasil penelitian tersebut dapat dirumuskan hipotesis sebagai berikut:

$\mathrm{H}_{4}$ : Kualitas informasi berpengaruh positif terhadap kepuasan pengguna

Kualitas layanan diukur dengan layanan akhir dari proses produksi, penyuplai pengolahan data, dan sebagian lainnya menitikberatkan pada hubungan layanan akhir yaitu antara staf yang melayani dan pengguna sistem. Petter et al. (2008) menyatakan bahwa kualitas layanan adalah kualitas dari system support dari departemen sistem informasi dan petugas teknologi informasi. Dari tiga peneliti yang meneliti pengaruh kualitas layanan terhadap penggunaan sistem tidak menemukan pengaruh yang signifikan dalam unit analisis individu (Petter et al., 2008), sedangkan untuk unit analisis organisasi hasil penelitian Wang dan Liao (2008), Mulyono (2009), Zaied (2012), Noviyanti (2016), Stefanovic et al. (2016) menemukan bahwa kualitas 
pelayanan berpengaruh signifikan terhadap penggunaan sistem. Berdasarkan hasil tersebut dapat dirumuskan hipotesis sebagai berikut:

$\mathrm{H}_{5}$ : Kualitas layanan berpengaruh positif terhadap penggunaan $e$-budgeting

Pengaruh kualitas layanan terhadap kepuasan pengguna masih beragam hasilnya. Hasil penelitian Wang dan Liao (2008), Mulyono (2009), Wahyuni (2011), Zaied (2012), Noviyanti (2016), Stefanovic et al. (2016) menemukan hubungan yang positif signifikan dalam arti bahwa kualitas layanan mempengaruhi kepuasan pengguna. Berdasarkan hasil penelitian tersebut dapat dirumuskan hipotesis sebagai berikut:

$\mathrm{H}_{6}$ : Kualitas layanan berpengaruh positif terhadap kepuasan pengguna

Penggunaan sistem adalah tingkat penggunaan sistem oleh staff dan user termasuk frekuensi, sifat penggunaan, kelayakan penggunan, tujuan penggunaan dan manfaat tambahan dari pemanfaatan sistem. (Petter et al., 2008). Penelitian terkait pengaruh kepuasan pengguna dengan penggunaan sistem masih beragam dalam penelitian Petter et al. (2008), lima peneliti menghasilkan pengaruh positif signifikan.Hasil penelitian Wang dan Liao (2008), Mulyono (2009), Wahyuni (2011), Zaied (2012), Noviyanti (2016), Stefanovic et al. (2016) menunjukkan bahwa penggunaan sistem berpengaruh terhadap kepuasan pengguna. Berdasarkan hasil penelitian tersebut dapat dirumuskan hipotesis sebagai berikut:

\section{$\mathrm{H}_{7}$ : Penggunaan e-budgeting}

berpengaruh positif terhadap kepuasan pengguna

Petter et al. (2008) menemukan bahwa pada unit analisis level organisasi, lima dari enam peneliti dalam artikelnya menemukan pengaruh positif signifikan. Kemudian hasil penelitian Wang dan Liao (2008), Mulyono (2009), Wahyuni (2011), Zaied (2012), Noviyanti (2016), Stefanovic et al. (2016) menunjukkan bahwa penggunaan sistem berpengaruh terhadap manfaat bersih. Berdasarkan hasil penelitian tersebut dapat dirumuskan hipotesis sebagai berikut:

\section{$\mathrm{H}_{8}$ : Penggunaan e-budgeting berpengaruh positif terhadap manfaat bersih $e$-budgeting}

Kepuasan pengguna adalah tingkat kepuasan yang terkait dengan penggunaan sistem mulai dari laporan, halaman web dan sistem pendukung (Petter et al., 2008). Pada penelitian yang dilakukan Petter et al. (2008) terdapat empat belas penelitian yang menghasilkan pengaruh yang positif signifikan dari hubungan kepuasan penggunan dan manfaat bersih. Hasil penelitian Wang dan Liao (2008), Mulyono (2009), Wahyuni (2011), Zaied (2012), Noviyanti (2016), Stefanovic et al. (2016) menunjukkan bahwa kepuasan penggunaan sistem berpengaruh terhadap manfaat bersih, sehingga dapat dirumuskan hipotesis sebagai berikut:

$\mathrm{H}_{9}$ : Kepuasan pengguna berpengaruh positif terhadap manfaat bersihe-budgeting

\subsection{Kerangka Penelitian}

Berdasarkan hasil penelitianpenelitian di atas, dapat dikembangkan kerangka berpikir sebagai berikut: 


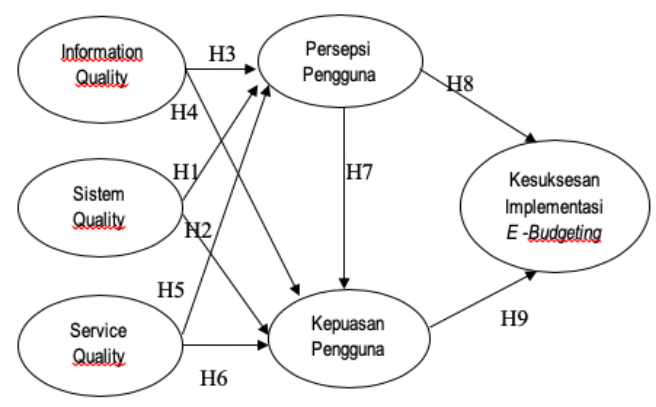

Sumber: Wang dan Liao (2008), Wahyuni (2011), Zaied (2012), Noviyanti (2016), Stefanovic (2016)

\section{3. METODE PENELITIAN}

Penelitian ini menggunakan metode observasi dan survei yaitu metode pengumpulan data primer yang diperoleh secara langsung dari sumber asli melalui kuesioner dan wawancara langsung dengan responden. Populasi dalam penelitian ini adalah Organisasi Perangkat Daerah (OPD) di pemerintah kota Surakarta yang terkait dengan penyusunan anggaran dengan menggunakan e-budgeting.

Pada penelitian ini sampel yang diambil adalah pengguna e-budgeting, sehingga teknik pengambilan sampel dalam penelitian ini dengan menggunakan purposive sampling yaitu pengambilan sampel berdasarkan kritera. Sehingga jumlah sampel yang ditentukan akan diseleksi kembali berdasarkan kriteria sebagai berikut:

1. SKPD Memiliki minimal 2 OPD

2. OPD memiliki admin/operator dan pimpinan

Model dalam penelitian ini adalah model hubungan berjenjang yaitu berupa sistem persamaan struktural. Penelitian ini menggunakan teknik statistik multivariate yang memungkinkan pengujian suatu hubungan kausal berjenjang. Dalam model ini akan diketahui hubungan secara berjenjang antar variabel. Dalam menganalisis jawaban yang diperoleh dari responden digunakan SEM melalui model pengukuran. Structural Equation Modeling (SEM) adalah teknik stratistik multivariate yang memungkinkan pengujian suatu rangkaian hubungan kualitas antar variabel.

\section{HASIL DAN PEMBAHASAN}

Jumlah responden dalam penelitian ini sebanyak 121 orang. Jumlah sampel ini memenuhi prosedur Maximum Likelihood Estimation yaitu penarikan sampel antara 100-200 sampel (Ghozali, 2008). Dalam uji normalitas hasil uji menunjukkan bahwa secara univariate data dalam penelitian ini termasuk normal yang ditunjukkan dengan nilai skewness $<2,58$. Secara multivariate, data dalam penelitian ini termasuk normal karena memiliki c.r kurtosis dibawah 7 yaitu sebesar 6,965.

Pengujian hipotesis dalam penelitian ini menggunakan analisis statistik Stuctural Equation Model (SEM) dengan alat analisis sofware Analysis of Moment Structure atau yang dikenal dengan AMOS. Adapun hasil olah data pada penelitian ini yaitu sebagai berikut:

Tabel 1: Hasil Uji SEM

\begin{tabular}{rrrrrrc}
\hline & $\begin{array}{r}\text { Regresion } \\
\text { Weight }\end{array}$ & Estimate & S.E. & C.R. & P \\
\hline PP & $<---$ & KS & 0,566 & 0,114 & 4,987 & 0,000 \\
PP & $<---$ & KI & 0,161 & 0,078 & 2,069 & 0,039 \\
PP & $<---$ & KL & 0,713 & 0,249 & 2,870 & 0,004 \\
\hline
\end{tabular}




\begin{tabular}{lrlrrrr}
\hline & $\begin{array}{r}\text { Regresion } \\
\text { Weight }\end{array}$ & Estimate & S.E. & C.R. & P \\
\hline KP & $<---$ & KS & 0,041 & 0,033 & 1,247 & 0,212 \\
KP & $<---$ & KI & $-0,026$ & 0,020 & $-1,316$ & 0,188 \\
KP & $<---$ & KL & 0,036 & 0,058 & 0,608 & 0,543 \\
KP & $<---$ & PP & 0,168 & 0,058 & 2,904 & 0,004 \\
SEB & $<---$ & PP & 0,360 & 0,136 & 2,651 & 0,008 \\
SEB & $<---$ & KP & 2,238 & 0,856 & 2,615 & 0,009 \\
\hline
\end{tabular}

Sumber : Hasil olah data, 2019

Adapun hasil uji hipotesis dalam penelitian ini pada tabel 1 dapat disimpulkan bahwa:

1. Pengaruh Kualitas Sistem Terhadap Persepsi Penggunaan

Perkembangan sistem informasi dan teknologi informasi saaat ini memudahkan bagi pemerintah untuk menyusun anggaran secara transparan dan akuntabel. Penggunaan teknologi informasi dalam penyusunan anggaran telah diterapkan di banyak pemerintah daerah, salah satunya adalah Pemerintah Kota Surakarta. Pemerintah Kota Surakarta telah menggunakan $e$ budgeting dalam penyusunan anggaran, sehingga semua stakeholders dapat memantau anggaran yang dibuat masingmasing SKPD. Sistem E-budgeting memberikan peranan yang penting dalam pembuatan anggaran. Sistem tersebut mampu mempersingkat waktu yang diperlukan dalam proses pembuatan anggaran karena dilakukan secara online dan dapat di akses dimana saja, namun efisiensi waktu tersebut dapat dicapai jika penggunaan sistem tersebut dapat dioperasionalkan dengan baik oleh penggunanya.

Kemudahan operasional sangat tergantung pada kualitas sistem itu sendiri. Kualitas sistem mencerminkan karakteristik kinerja dari sistem yang bersangkutan (DeLone dan McLean, 1992). Karakteristik yang diinginkan dari sebuah sistem informasi, misalnya: kemudahan penggunaan, sistem fleksibilitas, keandalan sistem, dan kemudahan mempelajarinya, termasuk adanya fitur yang intuitif, kecanggihan, fleksibilitas, dan waktu respon (Petter $e t$ al., 2008). Hasil penelitian ini menunjukkan bahwa kualitas sistem berpengaruh positif terhadap persepsi penggunaan e-budgeting. Hal ini menunjukkan bahwa sistem $e$-budgeting yang dipakai dipersepsikan penggunaannya dengan baik oleh pengguna. Hasil penelitian ini mendukung penelitian yang dilakukan oleh Wu dan Wang (2006), Wang dan Liao (2008), Mulyono (2009), Wahyuni (2011), Zaied (2012), Noviyanti (2016), Putra dan Alfian (2016), Stefanovic et al. (2016) yang menyatakan bahwa kualitas sistem berpengaruh positif dan signfikan terhadap persepsi penggunaan.

2. Pengaruh Kualitas Sistem terhadap kepuasan pengguna

Kualitas sistem e-budgeting memberikan peranan yang penting dalam pembuatan anggaran. Sistem tersebut mampu mempersingkat waktu yang diperlukan dalam proses pembuatan anggaran karena dilakukan secara online dan dapat di akses dimana saja. Sistem ini juga berfungsi sebagai alat pengawasan kerja yang dapat memantau poses dalam penyusunan anggaran. Selain itu, prosedur dalam E-budgeting juga dapat mengantisipasi potensi adanya mark-up dengan adanya sistem saling mengawasi. Oleh karena itu kualitas sistem informasi 
yang baik akan memudahkan pengguna dalam mengaplikasikannya dan memudahkan dalam melakukan kontrol terhadap anggaran. Hal ini dapat menimbulkan kepuasan bagi penggunanya.

Akan tetapi penelitian ini menunjukkan bahwa kualitas sistem informasi e-budgeting berpengaruh tidak signifikan terhadap kepuasan pengguna e-budgeting. Hal ini dapat disebabkan bahwa kualitas sistem informasi yang digunakan oleh Pemkot Surakarta, masih harus diperbaiki lagi sehingga lebih memudahkan pengguna dalam mengoperasikan sistem tersebut. Hal ini tidak mendukung penelitian yang dilakukan oleh Wu dan Wang (2016), Wang dan Liao (2008), Wahyuni (2011), Zaied (2012), Noviyanti (2016), Stefanovic et al. (2016) yang menyatakan bahwa kualitas sistem berpengaruh positif dan signfikan terhadap kepuasan pengguna. Akan tetapi penelitian ini mendukung penelitian dari Putra dan Alfian (2016) yang menyatakan bahwa kualitas sistem tidak berpengaruh terhadap kepuasan pengguna.

3. Pengaruh Kualitas Informasi Terhadap Persepsi Penggunaan

Kualitas informasi adalah karakteristik yang diinginkan dari output sistem informasi yaitu, laporan manajemen dan halaman web yang relevan, dapat dimengerti, akurasi, keringkasan, kelengkapan, ketepatan waktu, dan kemanfaatan (Petter et al., 2008). Kualitas informasi merupakan ukuran dari kualitas output dari sistem informasi, termasuk di dalamnya bentuk laporan yang dihasilkan sistem (DeLone dan McLean, 1992). Kualitas informasi menitikberatkan pada hal yang relevan, batas waktu yang tepat, dan akurat yang dihasilkan dari sistem informasi. Kualitas informasi pada e-budgeting pemerintah kota Surakarta saat ini berjalan dengan baik dan hasil penelitian ini menunjukkan bahwa kualitas informasi berpengaruh positif dan signifikan terhadap penggunaan e-budgeting. Hal ini berarti informasi yang lengkap, mudah untuk dipahami, mudah untuk di akses, aman dan akurat dapat meningkatkan persepsi penggunaan e-budgeting. Hasil penelitian ini mendukung penelitian yang dilakukan oleh Wu dan Wang (2006), Wang dan Liao (2008), Mulyono (2009), Wahyuni (2011), Zaied (2012), Noviyanti (2016), dan Stefanovic et al. (2016).

4. Pengaruh Kualitas Informasi Terhadap Kepuasan Pengguna

Kualitas informasi yang baik, yaitu dapat dimengerti, akurasi, keringkasan, kelengkapan, ketepatan waktu, dan memberikan manfaat dapat menumbuhkan kepuasan bagi penggunanya. Hasil penelitian ini menunjukkan bahwa kualitas informasi berpengaruh negatif, namun tidak signifikan. Hal ini dapat disebabkan kualitas informasi sistem e-budgeting di Pemerintah Kota Surakarta belum dapat dipahami dengan baik oleh penggunanya. Hasil penelitian ini mendukung penelitian yang dilakukan oleh $\mathrm{Wu}$ dan Wang (2006), Petter et al. (2008), Wang dan Liao (2008), Mulyono (2009), Wahyuni (2011), Zaied (2012), Putra dan Alfian (2016), Noviyanti (2016), Stefanovic et al. (2016), hasilnya menunjukkan bahwa kualitas informasi 
berpengaruh signifikan terhadap kepuasan pengguna.

5. Pengaruh Kualitas Layanan Terhadap Penggunaan e-budgeting

Sistem e-budgeting yang digunakan oleh pemerintah kota Surakarta relatif masih baru, oleh karena itu perlu layanan bagi pengguna $e$ budgeting agar memahamai mekanisme kerja yang benar terkait dengan $e$ budgeting. Kualitas layanan diukur dengan layanan akhir dari proses produksi, penyuplai pengolahan data, dan sebagian lainnya menitikberatkan pada hubungan layanan akhir yaitu antara staf yang melayani dan pengguna sistem. Hasil penelitian ini menunjukkan bahwa kualitas layanan berpengaruh positif dan signifikan terhadap penggunaan $e$ budgeting. Pengaruh positif menunjukkan bahwa semakin baik layanan yang diberikan kepada pengguna e-budgeting akan semakin meningkatkan persepsi penggunaan e-budgeting semakin baik. Petter et al. (2008) menyatakan bahwa kualitas layanan adalah kualitas dari system support dari departemen sistem informasi dan petugas teknologi informasi. Hasil penelitian ini mendukung penelitian yang dilakukan oleh Wang dan Liao (2008), Zaied (2012), Noviyanti (2016), dan Stefanovic et al. (2016) yang menemukan bahwa kualitas pelayanan berpengaruh signifikan terhadap penggunaan sistem.

6. Pengaruh Kualitas Layanan Terhadap Kepuasan Pengguna

Pelayanan kepada pengguna $e$ budgeting di lingkungan pemerintah kota Surakarta saat ini masih terus ditingkatkan, dan hasilnya menunjukkan bahwa pelayanan yang telah diberikan dipersepsikan baik oleh pengguna $e$ budgeting. Namun, hasil penelitian ini menunjukkan bahwa kualitas pelayanan tidak berpengaruh signifikan terhadap kepuasan pengguna. Hasil penelitian ini tidak mendukung penelitian Wang dan Liao (2008), Wahyuni (2011), Zaied (2012), Noviyanti (2016), Stefanovic et al (2016) menemukan hubungan yang positif signifikan dalam arti bahwa kualitas layanan mempengaruhi kepuasan pengguna.

7. Pengaruh Persepsi Penggunaan Terhadap Kepuasan Pengguna

Penggunaan sistem e-budgeting merupakan tingkat penggunaan sistem oleh pengguna seperti staff dan user termasuk frekuensi, sifat penggunaan, kelayakan penggunaan, tujuan penggunaan dan manfaat tambahan dari pemanfaatan sistem. Persepsi kemudahan penggunaan sistem yang baik akan meningkatkan kepuasan pengguna sistem tersebut. Hasil penelitian ini menunjukkan bahwa persepsi penggunaan berpengaruh positif dan signifikan terhadap kepuasan pengguna. Artinya, semakin baik persepsi pengguna terhadap e-budgeting akan semakin meningkatkan kepuasan pengguna. Hasil penelitian ini mendukung hasil penelitian Wu dan Wang (2006), Petter et al. (2008), Wang dan Liao (2008), Wahyuni (2011), Zaied (2012), Noviyanti (2016), Stefanovic et al. (2016) yang menyatakan bahwa penggunaan sistem berpengaruh terhadap kepuasan pengguna. 
8. Pengaruh Persepsi Penggunaan terhadap Kinerja e-budgeting

Sistem e-budgeting yang mudah, efektif, mampu meningkatkan produktivitas, aman, dan meminimalisir resiko dapat meningkatkan persepsi penggunanya terhadap sistem tersebut. Persepsi yang baik atas penggunaan sistem e-budgeting dapat meningkatkan kinerja penggunanya. Hasil penelitian ini menunjukkan bahwa persepsi penggunaan e-budgeting berpengaruh positif dan signifikan terhadap kinerja $e$ budgeting. Pengaruh positif menunjukkan bahwa semakin mudah, efektif dapat meningkatkan kinerja penggunaan $e$-budgeting. Hasil penelitian ini mendukung penelitian Petter et al. (2008) yang menemukan bahwa pada unit analisis level organisasi, lima dari enam peneliti dalam artikelnya menemukan pengaruh positif signifikan. Kemudian hasil penelitian Wang dan Liao (2008), Mulyono (2009), Wahyuni (2011), Zaied (2012), Noviyanti (2016), Stefanovic et al. (2016) yang menyatakan bahwa penggunaan sistem berpengaruh terhadap manfaat bersih.

9. Pengaruh kepuasan pengguna terhadap kinerja e-budgeting.

Kepuasan pengguna adalah tingkat kepuasan yang terkait dengan penggunaan sistem mulai dari laporan, halaman web dan sistem pendukung (Petter et al., 2008). Hasil penelitian ini menunjukkan bahwa kepuasan pengguna berpengaruh positif terhadap kesuksesan atau kinerja e-budgeting. Pengaruh positif berarti bahwa semakin tinggi tingkat kepuasan pengguna akan semakin meningkatkan keberhasilan penerapan $e$ - budgeting. Hasil penelitian ini mendukung penelitian yang dilakukan oleh Petter et al. (2008) terdapat empat belas penelitian yang menghasilkan pengaruh yang positif signifikan dari hubungan kepuasan penggunan dan manfaat bersih. Hasil yang sama dilakukan oleh Wu dan Wang (2006), Wang dan Liao (2008), Mulyono (2009), Wahyuni (2011), Zaied (2012), Noviyanti (2016), Putra dan Alfian (2016), Stefanovic et al. (2016) yang menyatakan bahwa kepuasan penggunaan sistem berpengaruh terhadap manfaat bersih.

\section{KESIMPULAN}

Penelitian ini membuktikan secara empiris pengaruh variabel yang terdapat dalam teori model kesuksesan sistem informasi yang diperkenalkan oleh DeLone dan McLean (2003). Hal ini menunjukkan bahwa sistem e-budgeting di Pemerintah Surakarta sudah berjalan dengan baik dari segi kualitas informasi dan kinerja, akan tetapi dari kualitas sistem masih harus secara serius diperbaiki karena masih banyak permasalahan dalam penyerapan anggaran dan belum terkontrolnya pelaksanaan anggaran oleh stakeholders yaitu "rakyat".

\section{KETERBATASAN DAN REKOMENDASI}

Penelitian ini mempunyai beberpa keterbatasan yaitu :

1. Penelitian ini hanya menggunakan responden pengguna e-budgeting pada 
titik waktu tertentu yaitu pada saat dilakukan survei.

2. Penelitian ini hanya dilakukan di pemerintah kota Surakarta saja, sehingga perlu kehati-hatian dalam menggeneralisir hasil penelitian untuk konteks yang lain dan tipe sistem informasi yang lain pula.

3. Penelitian ini menggunakan model yang dikembangkan di luar negeri dan kemungkinan kurang sesuai dengan kondisi di Indonesia.

Berdasarkan hasil penelitian dan keterbatasan diatas, untuk penelitian yang akan datang perlu memperhatikan hal-hal yang ada dibawah ini :

1. Memperbanyak jumlah sampel penelitian sesuai dengan rule of tumb pada SEM, sehingga dapat dilakukan pengujian secara serentak menggunakan teknik estimasi WLS.

2. Mengembangkan obyek penelitian, sehingga hasil penelitian ini dapat digeneralisasi.

3. Perlu upaya berkelanjutan untuk meningkatkan validitas dan model riset, baik basis teori maupun penerapan empirisnya, khususnya dikaitkan dengan kondisi lokal (konteks Indonesia).

\section{DAFTAR PUSTAKA}

Al-Fraihat, D., Joy, M., \& Sinclair, J. 2017. Identifying success factors for $e$ learning in higher education. International conference on elearning ( 247-255). Academic Conferences International Limited.

Balaban, I., Mu, E., dan Divjak, B. 2013. Development of An Electronic Portfolio System Success Model:
An Information Systems

Approach. Computers \&

Education. Vol 60, 396-411.

Baridwan, Z. 2005. Sistem informasi akuntansi. Badan Penelitian Fakultas Ekonomi Universitas Gajah Mada, Yogyakarta.

DeLone, W. H., \& McLean E. R. 1992. Information System Success: The Quest for the dependend variable. Information System Research (IRS). Vol 3 (1), 60-95.

DeLone, W. H., \& McLean, E. R. 2003. The DeLone and McLean model of Information Systems Success: A Ten-Year Update. Journal of Management Information Systems. Vol 19 (4), 9-30.

Fajri, R. N., Djumali, \& Hartono, S. 2019. Analisis Pengaruh Penerapan Sistem Informasi Keuangan, Sistem Pengawasan Melekat Dan Prinsip Transparansi terhadap Akuntabilitas Pengelolaan Anggaran Pendapatan dan Belanja Daerah (APBD) (Studi Empiris pada DPRD Kabupaten Rembang). Jurnal Balance, XVI (1), 64-83.

Gunawan, Dimas. R. 2016. Penerapan Sistem E-budgeting terhadap Transparansi dan Akuntabilitas Keuangan Publik (Studi pada Pemerintah Kota Surabaya). Akrual Jurnal Akuntansi. Vol 8 (1), 72-102. 
Khoirunnisak, R., Arishanti, D., dan Vebrianti, D. D. 2017. Penerapan E-budgeting Pemerintah Kota Surabaya dalam Mencapai Good Governance. Prosiding Seminar Nasional dan Call For Paper Ekonomi dan Bisnis (SNAPEREBIS 2017), (249-256). Jember.

Laudon, K., \& Laudon, J. 2006. Management Information Systems. Pearson/Prentice Hall, (9th ed). New Jersey.

Mulyono, I. 2009. Uji Empiris Model Kesuksesan Sistem Informasi Keuangan Daerah (SIKD) Dalam Rangka Peningkatan Transparansi dan Akuntabilitas Keuangan Daerah. Jurnal Ilmiah Akuntansi. SNA 12.

Nasution, D. A. D., Erlina, dan Sari, T. A. 2016. Analisis Faktor-Faktor yang Mempengaruhi Implementasi SAP Berbasis Akrual dengan Komitmen SKPD sebagai Variabel Moderating Pada Pemerintah Provinsi Sumatera Utara. Jurnal Ekonomi. Vol 19 (4).

Nasution, D. A. D., dan Ramadhan, P. J. 2019. Pengaruh Implementasi Ebudgeting Terhadap Transparansi Keuangan Daerah Indonesia. E-Jurnal Akuntansi. Vol 28 (1), 669-693.

Noviyanti. 2016. Mengukur Kesuksesan Sistem Akuntansi Instansi Basis
Acrual (SAIBA) menggungakan Model De Lone dan Mc Clean. Jurnal Tata Kelola \& Akuntabilitas Publik. Vol 2 (2).

Pemerintah Kota Surakarta. 2018. Laporan Pejabat Pengelola Informasi dan Dokumentasi (PPID).

Petter, Stacie., DeLone, W., dan McLean, Ephrim. 2008. Measuring Information Systems Success : Models, Dimensions, Measures, and Interrelationships. European Journal of Information System. Vol 17 , Issue 3.

Putra, W. M., dan Alfian, Muh. 2016. Pengujian Kesuksesan Implementasi Sistem Informasi Akuntansi Lembaga Keuangan Mikro: Modified Delone Mcleon Model. Jurnal Akuntansi dan Investasi. Vol 17 (1).

Purwohandoko, Sanaji, dan Mustofa, Ali. 2015. The Successful Implementation of E-Budgeting In Public University: A Study at Individual Level. Journal of Advances in Information Technology. Vol.6 (3), Surabaya.

Rokhman, A. 2011. E-government Adoption In Developing Countries; The Case Of Indonesia. Journal of Emerging Trend In Computing and Information Series. Vol 2 (5).

Romney, M. B. \& Paul J. S. 2012. Accounting Information Systems, 12/E. Pearson Prentice Hall. 
Soegoto, E. S., dan Indra, S.H.2018. Implementation Of E-budgeting Information System On Budget Management PT. Industri Telekomunikasi Indonesia. IOP Conference Series: Materials Science and Engineering. Vol 407.

Stefanovic, Darko; Marjanovic, Ugljesa;

Delic, Milan; Culibrk, Dubravko; LalicBojan. 2016. Assessing The Success of eGovernment Systems: An Employee Perspective. Information \& Management. Vol 53, 717-726.

Suara Merdeka. 2019. E-budgeting Jateng. https://www.suaramerdeka.com/ news/baca/17864/e-planningdan-e-budgeting-pemprovjateng-terbaik. (diakses 13 Desember 2019).

Thomas, B. 2008. Manajemen Kepemimpinan dan Kolaboasi dalam Dunia Kerja Kompetitif. Penerbit Salemba Empat: Jakarta.

Wahyuni, Trisacti. 2011. Uji Empiris Model DeLone dan McLean Terhadap Kesuksesan Sistem Informasi Manajemen Daerah (SIMDA). Jurnal BPPK, Vol 2.

Wang, Yi-Shun; Liao, Yi-Wen. 2008. Assessing E-government Systems Success: A validation of The DeLone and McLean Model of Information Systems Success.
Government Information

Quarterly, Vol 25, 717-733.

West, D. M. 2002. Global Egovernment. http://www.insidepolitics.org/eg ovt02int.html (diakses 13 Desember 2019).

Wu, J. H., dan Wang, Y. M. 2006. Measuring KMS Success: A Respecification of The DeLone and McLean's Model. Information and Management, Vol 43(6), 728739.

Zaied, Abdel, N. 2012. An Integrated Success Model for Evaluating Information Systemin Public Sectors. Journal of Emerging Trends in Computing and Information Sciences. Vol 3 (6).

Zeyn, E. 2011. Pengaruh Good Governance dan Standar Akuntansi Pemerintahan Terhadap Akuntabilitas Keuangan Dengan Komitmen Organisasi Sebagai Pemoderasi. Jurnal Reviu Akuntansi Keuangan. Vol 1 (1). 